\title{
Changes in renal function in response to protein restricted diet in Type 1 (insulin-dependent) diabetic patients
}

\author{
M.J. Wiseman, E. Bognetti, R. Dodds, H. Keen and G. C. Viberti \\ Unit for Metabolic Medicine, Division of Medicine, United Medical and Dental Schools, Guy's Campus, London, UK
}

\begin{abstract}
Summary. Glomerular filtration rate, renal plasma flow and urinary albumin excretion rate were measured during insulininduced euglycaemia in 12 male Type 1 (insulin-dependent) diabetic patients after a 3-week period of low protein diet $(45 \mathrm{~g} /$ day) or a similar period on unchanged conventional diet ( $103 \mathrm{~g} /$ day). No changes in glycaemic control, indicated by home blood glucose profiles and serum fructosamine concentration, or in arterial pressure, were noted on either diet. On low protein diet, glomerular filtration rate was lower $(p<$ 0.001 ) in all patients, but there was no difference in renal plasma flow between low protein diet and normal protein diet; fil-
\end{abstract}

tration fraction fell significantly on low protein diet $(p<$ $0.001)$. Fractional clearance of albumin was also lower $(p<$ 0.05 ) on low protein diet. This study suggests that reduction of dietary protein induces, independently of changes in plasma glucose and arterial pressure, modifications in glomerular filtration rate, filtration fraction and fractional clearance of albumin, which may be associated with a beneficial effect on the evolution of diabetic renal disease.

Key words: Glomerular filtration rate, albumin clearance, dietary protein, Type 1 (insulin-dependent) diabetes.
Increases in glomerular flow and pressure have been implicated in the genesis of the renal lesions of experimentally diabetic animals and in the initiation of the process leading to nephropathy in human patients with Type 1 (insulin-dependent) diabetes [1-3]. These haemodynamic disturbances have been shown to precede the exponential rise in proteinuria culminating in irreversible renal damage [4]. Increased intraglomerular pressure has been suggested as a common determinant of increases in both glomerular filtration rate (GFR) and albuminuria [4]. In human diabetic patients, strict blood glucose control can reduce glomerular hyperfiltration and prevent a further increase of subclinically elevated albumin excretion rate (AER) [5-7]. Relaxation of diabetic control is rapidly followed by elevations of both GFR and albuminuria [5, 8].

In the experimentally diabetic rat, reduction of intraglomerular hypertension, either by administration of an angiotensin converting enzyme inhibitor or by feeding a diet reduced in protein, appears to prevent not only the glomerular hyperfiltration and albumin hyperexcretion, but also the renal histological sequelae of diabetes, independently of the metabolic disturbance $[4,9]$.

It may be of importance, therefore, to ascertain whether in diabetic man manoeuvres other than blood glucose control may influence renal function. In this study, we have examined the effect of a low protein diet on GFR and AER in Type 1 diabetic patients, and explored the haemodynamics of the putative renal changes.

\section{Subjects and methods}

Diabetic patients were recruited from a screening program of the Diabetic Clinics of the Guy's group of hospitals. All were non-obese, ketosis-prone Caucasian males, with no history or evidence of cardiovascular disease, arterial hypertension $(>160 / 95 \mathrm{mmHg}$ ), urinary tract infection or any other renal tract disease, and were on no medication other than insulin.

Twelve Type 1 (insulin-dependent) diabetic patients were randomly allocated to take in turn a low protein diet (LPD) or to continue

Table 1. Clinical details of 12 male Type 1 diabetic patients. Figures are mean with ranges in brackets

\begin{tabular}{lllll}
\hline $\begin{array}{l}\text { Age } \\
\text { years })\end{array}$ & $\begin{array}{l}\text { Diabetes } \\
\text { duration } \\
\text { (years) }\end{array}$ & $\begin{array}{l}\text { Mean blood } \\
\text { pressure } \\
(\mathrm{mmHg})\end{array}$ & $\begin{array}{l}\text { Glomerular } \\
\text { filtration rate } \\
(\mathrm{ml} / \mathrm{min} / \\
\left.1.73 \mathrm{~m}^{2}\right)\end{array}$ & $\begin{array}{l}\text { Renal plasma } \\
\text { flow } \\
(\mathrm{ml} / \mathrm{min} / \\
\left.1.73 \mathrm{~m}^{2}\right)\end{array}$ \\
\hline 28.7 & 10.5 & 88.7 & $\begin{array}{l}133.4 \\
(102-200)\end{array}$ & $\begin{array}{l}604.9 \\
(410-932)\end{array}$ \\
\hline
\end{tabular}

a Diastolic $+1 / 3$ pulse pressure 
with their standard diet (NPD) for a 3-week period. There was at least a 1-week interval on NPD between the two diet periods, which each individual completed within 3 months. Measurements were made at recruitment into the study and at the end of each 3-week study period. Clinical details are given in Table1. All patients gave informed consent to the study, which was approved by the Guy's Hospital Ethical Committee.

\section{Dietary assessment}

Diet was assessed at baseline and then during the last 2 weeks on both LPD and NPD. All patients were interviewed and their recall of customary foods and beverages recorded. Specific questions concerned the frequency of meals, the number purchased outside the home, alcohol consumption, the addition of salt to foods and action in the event of hypoglycaemia. A 3-day food record was chosen as a quantitative method which fulfils the minimum requirements for assessing an individual's intake without placing unreasonable demands on the patient [10].

Detailed verbal and written instructions on the method of carrying out a weighed, 3-day food record were given. Self-zeroing scales (Soehnle 8001, Murrhardt, FRG) and standard forms were supplied. Two weekdays and one weekend day were included in the assessment to render the record as representative as possible. Every effort was made to minimise any concern that the records would be judged "right" (good) or "wrong" (bad). Foods eaten away from home were described in detail and quantities estimated in household measures. Records were checked with each patient to clarify terms, weights, recipes and cooking methods, and were then coded and analysed using the DIET programme on the University of London Computer, UK.

In addition to the weighed food records, each patient performed at home four 24-h urine collections, one during each of the last 2 weeks on both diets, for the determination of creatinine, sodium, phosphate, calcium and urea excretion to obtain objective measures of protein intake and compliance. The means of the two collections during both diet periods were used for calculation. Fasting plasma samples for urea determination were taken at the end of each study period.

The low-protein diet (LPD) as prescribed provided $40 \mathrm{~g}$ protein per day with half from animal sources and half from vegetable sources. The diet was designed to be isocaloric with the patients' normal diabetic diet with $35 \%$ of the energy from fat and $57-60 \%$ of energy from carbohydrate. This necessitated the use of special low protein, high carbohydrate products such as bread, crackers, pasta, flour and biscuits (GF Dietary Supplies, Stanmore, UK), which are low in dietary fibre. In order to maintain similar fibre intakes on the two diets, patients were encouraged, where appropriate, to eat high fibre foods. As cereal fibre is often linked to protein, sources of vegetable fibre poor in protein were used more often in LPD than NPD. Calcium (range 200-800 mg/day; mean $533 \mathrm{mg} /$ day) and phosphate tablets (phosphorus range $500-1000 \mathrm{mg} /$ day; mean $750 \mathrm{mg} /$ day) were prescribed to supplement the LPD to the same level of intake as the usual diet.

Patients were weighed unshod in indoor clothing at the same time of day on the night prior to each clearance study.

\section{Glycaemic control}

All patients were taught to provide capillary blood samples using capillary tubes dusted with sodium fluoride [11]. On one day in each of the last 2 weeks of the prescribed diet, patients performed a 7-point blood glucose profile (before and $2 \mathrm{~h}$ after each main meal and at bedtime) using these tubes, which were then sent within $24 \mathrm{~h}$ to our Metabolic Ward Laboratory for estimation. Blood samples when so handled provide consistent results for glucose over this period of time [12]. Each patient took these samples at the same times of day for each collection day, and the mean of the 2 samples at each time point was used for calculation.
In addition, serum fructosamine was measured at the end of each 3 -week period. Normal range (mean $\pm 2 \mathrm{SD}$ ) for fructosamine in our laboratory is $1.8-2.7 \mathrm{mmol} / 1$.

\section{Renal function estimation}

Renal function was measured at entry into the study and at the end of each diet period. All renal function assessments were made after overnight intravenous insulin infusion had rendered the patients normoglycaemic and during a steady state of water diuresis.

Patients were admitted to a Metabolic Ward at 18.00 hours the evening prior to the study. The usual evening insulin injection was omitted, and an indwelling teflon cannula (Venflon, Viggo, UK) was inserted under local anaesthesia into a antecubital vein. An infusion of insulin (Actrapid, Novo, $1.0 \mathrm{U} / \mathrm{ml}$ in normal saline $(0.9 \mathrm{~g} / \mathrm{dl}$ )) was then started and adjusted on the basis of hourly capillary plasma glucose measurements to maintain euglycaemia, i.e. plasma glucose between 3.5 and $6.5 \mathrm{mmol} / 1$. After 22.00 hours all food and drink other than tap water was prohibited. Between 07.00 hours and 08.00 hours the next morning patients drank 1.51 of tap water, followed by $200 \mathrm{ml}$ every $20 \mathrm{~min}$ until a steady state of water diuresis was attained. This was maintained throughout the study by replacing urinary losses with tap water. Actual mean $( \pm$ SEM) urine flows obtained were $10.7 \pm$ $1.0 \mathrm{ml} / \mathrm{min}$ on LPD and $12.0 \pm 1.0 \mathrm{ml} / \mathrm{min}$ on NPD. Two teflon cannulae (Venflon, Viggo, UK) were then inserted under local anaesthesia: one in the same arm as the insulin infusion through which bolus doses of polyfructosan (INUTEST, Boehringer Mannheim, Switzerland, $3.5 \mathrm{~g}$ in $35 \mathrm{ml}$ of water) and sodium paraminohippurate (PAH) (Merck, Sharpe and Dohme, Hertfordshire, UK, $600 \mathrm{mg}$ in $3 \mathrm{ml}$ of water) were given, followed by an infusion of polyfructosan $(40 \mathrm{mg} /$ min) combined with PAH $(14 \mathrm{mg} / \mathrm{min}$ in saline $9 \mathrm{~g} / \mathrm{dl}(0.154 \mathrm{mmol} /$ 1)) at a rate of $0.6 \mathrm{ml} / \mathrm{min}$. The second cannula was placed into a vein in the other antecubital fossa for blood sampling. After $45 \mathrm{~min}$ equilibration, four exactly timed urine collection periods of approximately 15 min each were made. At the mid-point of each urine collection period, pulse rate was taken, blood pressure (phase I/V) was measured to the nearest $2 \mathrm{mmHg}$ using a standard mercury sphygmomanometer by a single observer (EB), and blood samples were drawn for measurement of PAH, polyfructosan, glucose, urea, creatinine, total plasma proteins, haematocrit and electrolytes. Patients remained supine throughout the study, standing only to void spontaneously. Urine volume was immediately measured and aliquots taken into plain tubes for measurements of $\mathrm{PAH}$, polyfructosan and electrolytes. A further $3.5 \mathrm{ml}$ aliquot was taken into a tube containing $20 \mu \mathrm{l}$ gelatine $(10 \mathrm{~g} / \mathrm{dl})$ and $20 \mu \mathrm{l} \mathrm{NaOH}(4 \mathrm{~mol} / 1)$ for measurement of urinary albumin and $\beta_{2}$ microglobulin concentrations, which were thus determined simultaneously with renal haenodynamic parameters. Samples were frozen and stored at $-20^{\circ} \mathrm{C}$ until assayed.

Polyfructosan is handled by the kidney in an identical fashion to inulin, and has been shown to be strictly comparable to inulin for the determination of renal clearance [13].

\section{Measurements}

Plasma glucose concentration was measured using a glucose oxidase method (Yellow Springs Analyzer, YSI Inc, Yellow Springs, Ohio, USA) for both home glucose profiles and during clearance procedures. Sodium, potassiurn, calcium, phosphate, urea and creatinine concentration were measured in urine and in plasma using a multichannel autoanalyzer (Vickers Medical, UK). Plasma and urinary albumin [6] and urinary $\beta_{2}$ microglobulin ( $\beta_{2}$ Micro RIA, Pharmacia Diagnostics AB, Uppsala, Sweden) concentrations were measured by radioimmunoassay, plasma total protein by refractometry and haematocrit by routine Coulter counter. Polyfructosan was measured by the method of Heyrovsky [14] and PAH by the method of Bratton and Marshall [15]. Inter- and intra-assay coefficients of variation were respectively $3.6 \%$ and $3.1 \%$ for INUTEST, and $4.0 \%$ and $1.1 \%$ for PAH. Fructosamine was measured by an automated technique [16] using a Cobas Bio Centrifugal analyser (Roche, UK). 
GFR and renal plasma flow (RPF) were calculated as the clearances of polyfructosan and PAH respectively. Clearances were calculated using the formula: Clearance $=\frac{U \times V}{P}$ where $U$ and $P$ are urinary and plasma concentrations respectively, and $\mathrm{V}$ is urine flow rate. Clearances were corrected to $1.73 \mathrm{~m}^{2}$ body surface area. Filtration fraction (FF) was calculated as GFR/RPF. Excretion rates of albu$\min (A E R)$ and $\beta_{2}$ microglobulin were calculated as $\mathrm{U}_{\mathrm{alb}}$ or $\mathrm{U}_{\beta 2 \mathrm{M}} \times \mathrm{V}$. Fractional clearance of albumin was calculated as $\frac{\mathrm{CAlb}}{\mathrm{CIn}}$ where $\mathrm{C}_{\mathrm{Alb}}$ and $\mathrm{C}_{\text {In }}$ are the clearances of albumin and polyfructosan respectively. Renal vascular resistance was calculated as

$\frac{\mathrm{MBP} \times(1-\mathrm{Ht})}{\mathrm{RPF}}$

where MBP is mean blood pressure calculated as diastolic blood pressure $+1 / 3$ pulse pressure, and $\mathrm{Ht}$ is haematocrit. All results represent the mean of the 4 measurements taken during the four 15-min experimental periods.

\section{Statistical analysis}

Data were analyzed by Student's t-test and Wilcoxon's test for paired data as appropriate [17], and by linear regression analysis. Analysis of variance was used to compare diurnal plasma glucose profiles. Urinary protein excretion results underwent logarithmic transformation prior to statistical analysis because of their positively skewed distribution. Statistical significance was taken as $p<0.05$. Except where otherwise stated, results are given as mean \pm SEM.

\section{Results}

\section{Dietary assessment}

Dietary data on the two diets are given in Table 2. A $57 \%$ reduction in total protein intake on LPD was calculated from the dietary assessment; this was supported by significant falls in plasma concentration $(p<0.01)$ and daily urinary excretion $(p<0.005)$ of urea (Table 3$)$.

Carbohydrate intake increased and fat intake decreased on the low protein diet. Total fibre intake did not change. There were no significant differences in either total calcium (NPD $1286 \pm 102 \mathrm{mg}$ /day versus LPD $1211 \pm 100 \mathrm{mg} /$ day) or phosphate intake (NPD $1189 \pm 104$ vs LPD $1835 \pm 115 \mathrm{mg}$ /day) on the two diets. Urinary excretion of sodium was similar on NPD $(176 \pm 24 \mathrm{mmol} / 24 \mathrm{~h})$ and LPD $(201 \pm 42 \mathrm{ml} / 24 \mathrm{~h})$, as was that of phosphate (NPD 28.1 \pm 3.5 ; LPD $30.3 \pm$ $6.6 \mathrm{mmol} / 24 \mathrm{~h}$ ). No significant differences were seen in fasting plasma concentrations of sodium, calcium, phosphate, potassium and creatinine or in the urinary excretion of creatinine, calcium and potassium between the two diets. There was a small fall in total energy intake on LPD, but body weight and plasma albumin concentrations were similar at the end of the two diets (Table 2).

\section{Renal function}

Results of renal function are given in Table 4 and Figure 1. GFR was lower $(p<0.001)$ in all subjects on LPD,
Table 2. Dietary data in 12 male Type 1 diabetic patients on normal protein diet and low protein diet. Figures are mean \pm SEM

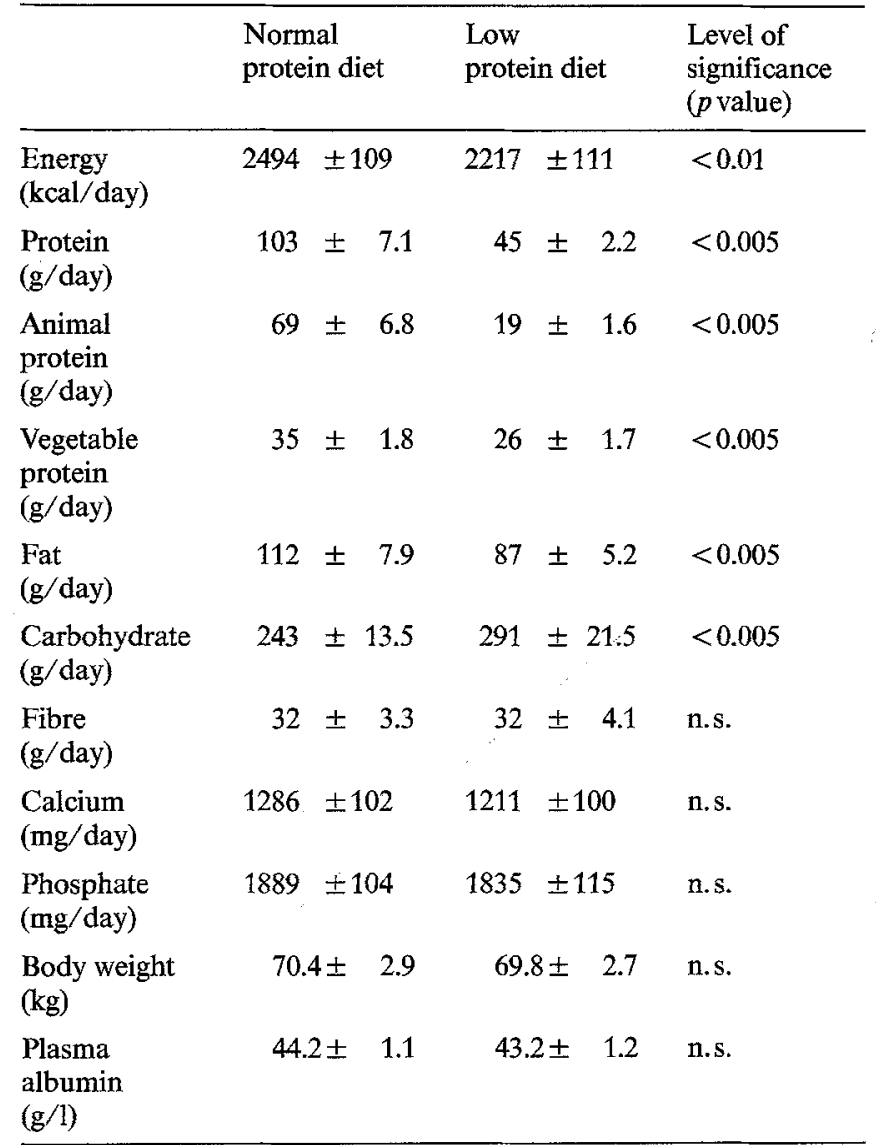

Table 3. Plasma concentration and urinary excretion of urea after normal protein diet and low protein diet in 12 male Type 1 diabetic patients. Figures are mean \pm SEM

\begin{tabular}{lrrl}
\hline & $\begin{array}{l}\text { Normal } \\
\text { protein diet }\end{array}$ & $\begin{array}{l}\text { Low } \\
\text { protein diet }\end{array}$ & $\begin{array}{l}\text { Significance level } \\
(p \text { value })\end{array}$ \\
\hline $\begin{array}{l}\text { Plasma urea } \\
(\mathrm{mmol} / \mathrm{l})\end{array}$ & $5.2 \pm 0.5$ & $2.9 \pm 0.2$ & $<0.01$ \\
$\begin{array}{l}\text { Urinary urea } \\
(\mathrm{mmol} / 24 \mathrm{~h})\end{array}$ & $433 \pm 19$ & $196 \pm 23$ & $<0.005$ \\
\hline
\end{tabular}

while RPF was similar at the end of each diet. FF was significantly lower at the end of LPD than NPD ( $p<$ 0.001 ). Calculated renal vascular resistance (RVR) was not different at the end of each diet (NPD 91.1 \pm 4.9 versus LPD $89.9 \pm 5.3 \mathrm{mmHg} \cdot \mathrm{min} \cdot \mathrm{ml}^{-1}$ ).

Urinary albumin excretion was lower in 10 of the 12 patients on LPD (geometric mean: LPD 1.0 (range $0.3-11.8$ ) vs NPD 3.1 (range $0.4-186$ ) $\mu \mathrm{g} / \mathrm{min}$ ), and fractional clearance of albumin was significantly lower ( $p<0.05$; t-test on logarithmically transformed values) after LPD than NPD (Table 4 and Fig.1). Urinary excretion of $\beta_{2}$ microglobulin was not significantly different after LPD or NPD (Geometric mean (range): LPD $186(48-322)$ vs NPD $176(162-264) \mu \mathrm{g} / \mathrm{min})$. 
Table 4. Glomerular filtration rate (GFR), renal plasma flow (RPF), filtration fraction (FF) and fractional clearance of albumin ( $\theta$ Alb) in 12 male Type 1 diabetic patients after 3 weeks of normal protein diet (NPD) or low protein diet (LPD)

\begin{tabular}{|c|c|c|c|c|c|c|c|c|}
\hline \multirow[t]{2}{*}{$\begin{array}{l}\text { Subject } \\
\text { no }\end{array}$} & \multicolumn{2}{|c|}{$\begin{array}{l}\text { Glomerular filtration rate } \\
\left(\mathrm{ml} / \mathrm{min} / 1.73 \mathrm{~m}^{2}\right)\end{array}$} & \multicolumn{2}{|c|}{$\begin{array}{l}\text { Renal plasma flow } \\
\left(\mathrm{ml} / \mathrm{min} / 1.73 \mathrm{~m}^{2}\right)\end{array}$} & \multicolumn{2}{|c|}{ Filtration fraction } & \multicolumn{2}{|c|}{$\begin{array}{l}\text { Fractional clearance } \\
\text { of albumin } \times 10^{-8}\end{array}$} \\
\hline & NPD & LPD & NPD & LPD & NPD & LPD & NPD & LPD \\
\hline 2 & 157 & 146 & 811 & 779 & 0.19 & 0.19 & 90.4 & 4.5 \\
\hline 3 & 168 & 159 & 810 & 909 & 0.21 & 0.17 & 3000.0 & 42.0 \\
\hline 4 & 135 & 117 & 635 & 562 & 0.23 & 0.21 & 103.0 & 102.0 \\
\hline 7 & 151 & 132 & 548 & 685 & 0.28 & 0.19 & 22.0 & 19.0 \\
\hline 8 & 123 & 122 & 457 & 547 & 0.27 & 0.22 & 100.0 & 140.0 \\
\hline 9 & 117 & 98 & 534 & 635 & 0.22 & 0.15 & 25.0 & 18.0 \\
\hline 10 & 124 & 96 & 531 & 536 & 0.23 & 0.18 & 21.0 & 7.1 \\
\hline 11 & 100 & 96 & 705 & 662 & 0.14 & 0.14 & 9.7 & 9.0 \\
\hline 12 & 110 & 96 & 545 & 513 & 0.20 & 0.19 & 10.5 & 8.0 \\
\hline
\end{tabular}

${ }^{a}$ For $\theta \mathrm{Alb}$, geometric means are given
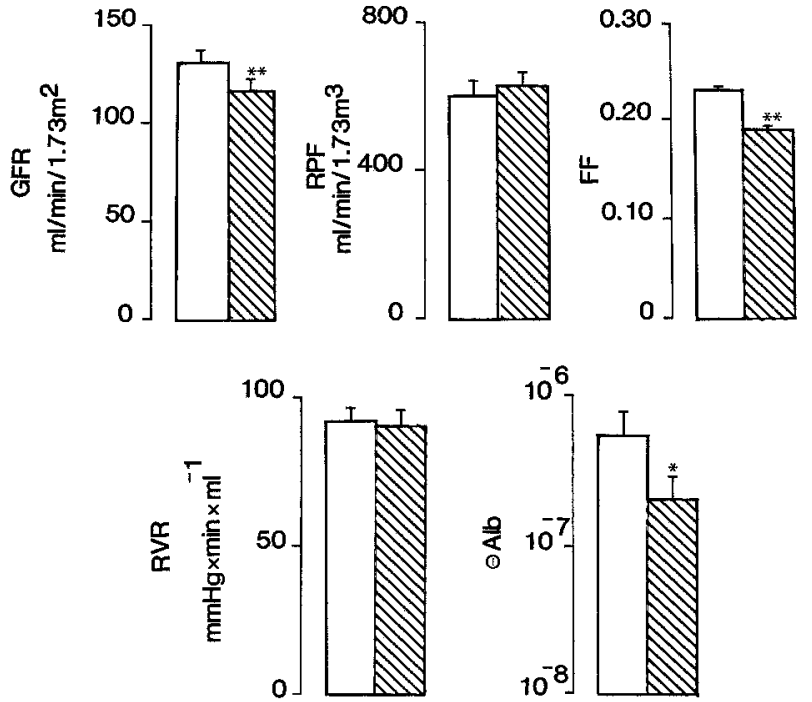

Fig. 1. Glomerular filtration rate (GFR), renal plasma flow (RPF), filtration fraction (FF), renal vascular resistance (RVR) and fractional clearance of albumin ( $\theta \mathrm{Alb}$; log scale) on normal protein diet (open bars) and low protein diet (hatched bars) in 12 male Type 1 diabetic patients. Data are means and SEM. ${ }^{* *}=p<0.001 ; *=p<0.05$

Plasma total protein did not differ significantly between the diets (NPD $66 \pm 1$; LPD $64 \pm 1 \mathrm{~g} / 1$ ). No correlation was found between values at entry of GFR, RPF or MBP and diet-induced differences in these variables or in albumin clearance.

\section{Blood glucose and arterial pressure}

Serum fructosamine was not significantly different at the end of each diet (NPD $3.5 \pm 0.2$ vs LPD $3.2 \pm$ $0.1 \mathrm{mmol} / 1$ ).

Plasma glucose profiles were similar during the two diets (Fig. 2) and plasma glucose concentrations during the clearance procedures after each diet were also simi$\operatorname{lar}$ (NPD $4.6 \pm 0.3$ vs LPD $4.8 \pm 0.2 \mathrm{mmol} / 1$ ). No change in mean daily insulin dosage was found between LPD and NPD, and insulin infusion rates during clearance procedures were similar during NPD $(0.64 \pm 0.06 \mathrm{U} / \mathrm{h})$ and LPD $(0.88 \pm 0.18 \mathrm{U} / \mathrm{h})$. No correlation was found between insulin infusion rate and any of the renal haemodynamic parameters considered. Arterial blood pressure was not significantly different after either diet (NPD: $\frac{116 \pm 3}{78 \pm 2} \mathrm{mmHg}$ vs LPD: $\frac{115 \pm 2}{77 \pm 3} \mathrm{mmHg}$ ).

\section{Discussion}

This study demonstrates that a diet restricted in total protein for 3 weeks significantly reduces glomerular filtration rate and fractional clearance of albumin in Type 1 (insulin-dependent) diabetic patients. This effect occurred independently of changes in plasma glucose concentration or systemic arterial blood pressure, and is consistent with the findings of studies in experimental diabetic animals [4].

That subjects complied with the diet is supported by objective measures of nitrogen metabolism (plasma and urinary urea) as well as dietary history and assessment. While a change in total protein intake was the prime aim of the dietary prescription, this of necessity entailed changes in the intake of other nutrients (e.g. fat and carbohydrate) and produced a fall of $277 \mathrm{Kcal}$ in total daily energy intake. Although the possibility cannot totally be excluded that any or all of these changes, singly or in combination, may have contributed to the observed renal functional alterations [18], there is considerable evidence that protein may be their major determinant [19]. Furthermore, changes in phosphate and sodium excretion which could have affected renal function did not occur during low protein diet in our patients. 


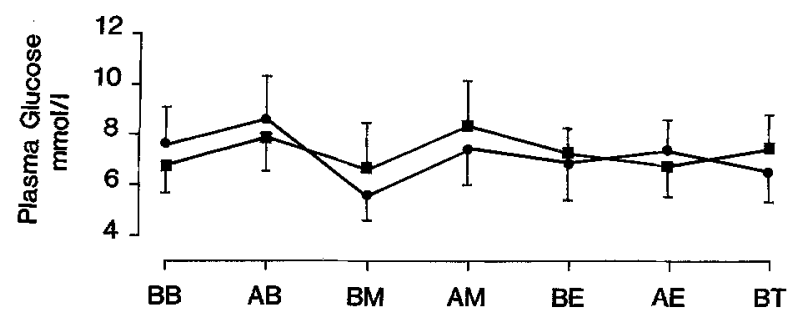

Fig. 2. Plasma glucose profiles in 12 male Type 1 diabetic patients during normal protein diet ( $)$ and low protein diet $(\boldsymbol{\square})$. $\mathrm{BB}=$ before breakfast; $\mathrm{AB}=$ after breakfast; $\mathrm{BM}, \mathrm{AM}=$ before and after midday meal, $\mathrm{BE}, \mathrm{AE}=$ before and after evening meal; and $\mathrm{BT}=$ bedtime

Three weeks of a protein restricted diet had an effect on GFR of similar magnitude to that achieved by nearnormoglycaemia only after 6 months [5]. The GFR fall was not accompanied by changes in RPF or in calculated total renal vascular resistance, but there was a significant fall in FF. The fraction of GFR not accounted for by RPF is determined by afferent oncotic pressure, mean transcapillary hydraulic pressure gradient $(\overline{\Delta \mathrm{P}})$ and ultrafiltration coefficient $\left(\mathrm{K}_{\mathrm{f}}\right)$ [20]. In this study plasma protein concentrations were similar on the two diets, indicating no difference in oncotic pressure. Thus, the fall in GFR must be the result of a change in $\overline{\Delta \mathrm{P}}$ or $\mathrm{K}_{\mathrm{f}}$ or a combination of them. However, in man, because direct measurements are not obtainable, it is impossible to distinguish between changes in these two determinants. In experimentally diabetic rats, a reduction in dietary protein intake greater than that in our study was not associated with a change in $\mathrm{K}_{\mathrm{f}}$, and the reduction of single nephron GFR was effected mainly by means of lower mean transglomerular pressure gradient [4]. The lower FF after LPD in the diabetic patients in our study is therefore consistent with a decrease of transglomerular hydraulic pressure difference. In some experimental situations such as infusion of angiotensin II or norepinephrine, changes in FF have been shown to parallel directly measured $\overline{\Delta P}$ changes [21]. In normal individuals the fall in GFR accompanying low protein feeding has been found by other authors [22,23] and ourselves (Viberti et al., unpublished observations) to be associated with a parallel reduction in RPF without change in FF. This suggests that a protein restricted diet may affect renal haemodynamic changes differently in diabetic patients from non-diabetic individuals. The changes in the present study occurred in the absence of alterations in other possible modulators of renal function, such as glycaemic control and systemic arterial pressure $[5,7,24]$. This supports the view that intrarenal haemodynamics in diabetes may be regulated by factors independent of the metabolic derangement or systemic arterial pressure. Whatever the mechanisms responsible for this effect, our findings suggest that some aspects of protein or amino-acid metabolism, either directly or via hormonal or neural mediation $[19,25]$, may be important for the expression of the haemodynamic disturbances of early diabetes.
These diabetic patients had albumin excretion rates which covered levels ranging from normal to supranormal, confirming previous observations [26]. The lower fractional clearance of albumin after low protein diet is in accord not only with findings in animal models of renal disease $[4,27]$, but also with preliminary reports of dietary protein restriction in diabetic humans with microalbuminuria [28]. There are a number of possible explanations for the observed reduction. A fall in the filtered load of albumin associated with the fall in GFR may explain part of the phenomenon. However, the fall in fractional clearance suggests that glomerular membrane permselectivity as well as intraglomerular haemodynamic changes are likely to have taken place. Which of the permeability properties of the membrane changed must at present remain speculative. Alternatively, a change in the tubular reabsorption of albumin may have occurred, as with this low degree of proteinuria tubular reabsorptive capacity may not be saturated [29]. However, the similar excretion rates on the two diets of $\beta_{2}$ microglobulin, one index of tubular function [30], suggests that tubular mechanisms for protein reabsorption were probably unchanged. The possibility remains that the tubular reabsorption of these two proteins may be differently affected by an intervention such as dietary modification [31].

In insulin-dependent diabetic humans, elevations of both GFR and AER have been associated with increased risk of later diabetic nephropathy $[1,30,32,34]$. Animal studies suggest that intraglomerular hypertension may be a common determinant of these abnormalities, which confers on them the association with increased risk of glomerular destruction $[4,9]$. Manoeuvres which specifically attentuate these intrarenal deviations may contribute $/$ in man to prevention or delay of the onset of diabetic renal disease.

Acknowledgements. We thank the Departments of Clinical Chemistry and Haematology at Guy's Hospital and Mr. T. Tariq and G. Scott for technical assistance. These studies were partly funded by the National Kidney Research Fund. RD was supported by GF Dietary Supplies Ltd., UK. Dr. Bognetti was a visiting Research Fellow from the 3rd Department of Paediatrics of the University of Milan, Italy and Ms.Jean Gray provided skilful secretarial help.

\section{References}

1. Hostetter TH, Rennke H, Brenner BM (1982) The case for intrarenal hypertension in the initiation and progression of diabetic and other glomerulopathies. Am J Med 72:375-380

2. Mauer SM, Steffes MW, Azar S, Sandberg SK, Brown DM (1978) The effects of Goldblatt hypertension on development of the glomerular lesions of diabetes mellitus in the rat. Diabetes 27 : 738-744

3. Steffes MW, Brown DM, Mauer SM (1978) Diabetic glomerulopathy following unilateral nephrectomy in the rat. Diabetes 27 : $35-41$

4. Zatz R, Meyer TW, Rennke HG, Brenner BM (1985) Predominance of haemodynamic rather than metabolic factors in the pathogenesis of diabetic glomerulopathy. Proc Natl Acad Sci USA 82: 5963-5967 
5. Wiseman MJ, Saunders AJ, Keen H, Viberti GC (1985) The effect of blood glucose control on increased glomerular filtration rate and kidney size in insulin-dependent diabetes. N Engl J Med 312: 617-621

6. Kroc Collaborative Study Group (1984) Blood glucose control and the evolution of diabetic retinopathy and albuminuria. $\mathrm{N}$ Engl J Med 311: 365-372

7. Feldt-Rasmussen B, Mathiesen ER, Deckert T (1986) Effect of two years strict metabolic control on progression of incipient nephropathy in insulin-dependent diabetes. Lancet 2: 1300-1304

8. Parving HH, Noer I, Deckert T, Evrin PE, Nielsen SL, Lynsgoe J, Mogensen CE, Rorth M, Svendsen PA, Trap-Jensen J, Lassen NA (1976) The effect of metabolic dysregulation on microvascular permeability to small and large molecules in short-term diabetics. Diabetologia 12: 161-166

9. Zatz R, Dunn BR, Meyer TW, Anderson S, Rennke HG, Brenner BM (1986) Prevention of diabetic glomerulopathy by pharmacological amelioration of glomerular capillary hypertension. J Clin Invest 77: 1925-1930

10. Eppwright ES, Patton MB, Marlatt AL, Hathaway ML (1952) Dietary study methods. V.Some problems in collecting dietary information about groups of children. J Am Diet Assoc 28: 43-48

11. Clark AJL, Bilous RW, Keen WL, Keen H (1982) Capillary tubes for blood glucose sampling. Diabetologia 23: 539-540

12. De Pasqua A, Mattock MB, Phillips R, Keen H (1984) Errors in blood glucose determination. Lancet 2: 1165

13. Nitsch E, Iwanov W, Lederer K (1979) Molecular characterisation of sinistrin. Carbohydrate Research 72:1-12

14. Heyrovsky A (1956) A new method for the determination of inulin in plasma and urine. Clin Chim Acta 1: 470-474

15. Bratton AL, Marshall EK (1938) A new coupling component for sulfanilamine determination. J Biol Chem 128: 537-550

16. Lloyd D, Marples J (1984) Simple colorimetry of glycated serum protein in a centrifugal analyzer. Clin Chem 30:1686-1688

17. Armitage $P$ (1971) Statistical methods in medical research. Blackwell, London

18. Laouari D, Kleinknecht C, Gubler ML, Broyer M (1983) Adverse effect of proteins on remnant kidney. Dissociation from that of other nutrients. Kidney Int 24 [Suppl 16]: S248-S253

19. Brenner BM, Meyer TW, Hostetter TH (1982) Dietary protein intake and the progressive nature of kidney disease: the role of haemodynamically mediated glomerular injury in the pathogenesis of progressive glomerular sclerosis in aging, renal ablation and intrinsic renal disease. N Engl J Med 307: 652-659

20. Brenner BM, Humes HD (1977) Mechanisms of glomerular ultrafiltration. N Engl J Med 297: 148-154

21. Myers BD, Deen WM, Brenner BM (1975) Effect of norepinephrine and angiotensin II on the determinants of glomerular ultrafiltration and proximal tubule fluid reabsorption in the rat. Cir Res 37: $101-110$
22. Pullman TN, Alving AS, Dean RJ, Landonne M (1954) The influence of dietary protein intake on specific renal functions in normal man. J Lab Clin Med 44: 320-332

23. Bergstrom S, Ahlberg M, Alvestrand A (1985) Influence of protein intake on renal haemodynamics and plasma hormone concentration in normal subjects. Acta Med Scand 217: 189-196

24. Parving HH, Jensen HA, Mogensen CE, Evrin PE (1974) Increased urinary albumin excretion rate in benign essential hypertension. Lancet 1: 1190-1192

25. Dworkin LD, Ichikawa I, Brenner BM (1983) Hormonal modulation of glomerular function. Am J Physiol 244: F95-F104

26. Viberti GC, Jarrett RJ, Wiseman MJ (1984) Predicting diabetic nephropathy. N Engl J Med 311: 1256-1257

27. El Nahas AM, Paraskevakou H, Zoob S, Evans DJ, Rees AJ (1983) Effect of dietary protein restriction on the development of renal failure after subtotal nephrectomy in rats. Clin Sci 65: 399-406

28. Cohen DL, Dodds R, Viberti GC (1987) Effect of protein restricted diet in insulin-dependent diabetics at risk of nephropathy. $\mathrm{Br}$ Med $\mathbf{J}$ (in press)

29. Landwehr DM, Carvalho JS, Oken DE (1977) Micropuncture studies of the filtration and absorption of albumin by nephrotic rats. Kidney Int 11:9-17

30. Peterson PA, Evrin PE, Bergaard I (1969) Differentiation of glomerular, tubular and normal proteinuria. Determinations of urinary excretion of $B_{2}$ microglobulin, albumin and total protein. $J$ Clin Invest 48: 1189-1198

31. Sumpio BE, Maack T (1984) Albumin absorption and catabolism by isolated perfused proximal convoluted tubules of the rabbit. J Clin Invest 73: 767-777

32. Viberti GC, Hill RD, Jarrett RJ, Argyropoulos A, Mahmud E, Keen $H$ (1982) Microalbuminuria as a predictor of clinical nephropathy in insulin-dependent diabetes mellitus. Lancet 1 : 1430-1432

33. Mathiesen ER, Øxenboll D, Johansen K, Svendsen PA, Deckert T (1984) Incipient nephropathy in Type 1 (insulin-dependent) diabetes. Diabetologia 26: 406-410

34. Mogensen CE, Christensen CK (1984) Predicting diabetic nephropathy in insulin-dependent patients. $\mathrm{N}$ Engl $\mathrm{J}$ Med 311: $89-93$

Received: 18 July 1986

and in revised form: 20 January 1987

Dr. Gian Carlo Viberti

Unit for Metabolic Medicine

4th Floor Hunt's House

Guy's Hospital

London SE1 9RT, UK 